\title{
MANAGEMENT OF ENDOCRINE DISEASE Paediatric Cushing's disease
}

\section{Helen L Storr and Martin O Savage}

Barts and the London School of Medicine and Dentistry, William Harvey Research Institute, Centre for Endocrinology, Queen Mary University of London, 1st Floor, John Vane Science Centre, Charterhouse Square, London EC1M 6BQ, UK
Correspondence should be addressed to H L Storr

Email

h.l.storr@qmul.ac.uk

\begin{abstract}
Cushing's disease (CD) is the commonest form of ACTH-dependent Cushing's syndrome and is a rare clinical diagnosis in paediatric and adolescent patients. CD is caused by an ACTH-secreting pituitary corticotroph adenoma and is associated with significant morbidity in children; therefore, early diagnosis and treatment are critical for optimal therapeutic outcome. This review highlights the key clinical and biochemical features of paediatric $C D$ and appraises current practices in diagnosis and management. A close liaison with adult endocrinology colleagues, particularly, for interpretation of investigations and definition of therapeutic strategy is strongly advised.
\end{abstract}

\section{Introduction}

Endogenous Cushing's syndrome (CS) is a rare lifethreatening disorder caused by prolonged exposure to excess glucocorticoid hormone concentrations. CS can be divided into adrenocorticotrophic hormone (ACTH)-dependent and ACTH-independent aetiological categories. Approximately, $10 \%$ of new CS cases each year occur in the paediatric age range up to 18 years, and Cushing's disease (CD) caused by an ACTH-secreting pituitary adenoma is responsible for $75-80 \%$ of cases. Once CS is suspected, the paediatric patient requires investigation using a formal protocol to ensure an accurate diagnosis and definition of the aetiology. Once CD has been diagnosed, the primary aim of treatment is rapid normalisation of serum cortisol, which is particularly important in children due to the adverse effects of prolonged hypercortisolaemia on growth and development. Once remission of the $\mathrm{CD}$ has been established, post-treatment management also presents challenges for optimisation of growth, pubertal development and body composition.

In this review, we discuss epidemiology, pathogenesis, clinical features, investigations and treatment of paediatric $\mathrm{CD}$. The recommendations are based on published data and our experience from the management of 47 cases of paediatric CD at St Bartholomew's and the Royal London Hospitals during the past 30 years.

\section{Epidemiology}

$\mathrm{CD}$ is the commonest cause of CS in children over 5 years of age $(1,2,3)$, accounting for $75-80 \%$ of paediatric CS cases compared with $49-71 \%$ of adult cases $(1,4)$. ACTH-

\section{Invited Author's profile}

Dr Helen Storr is Reader and Honorary Consultant in Paediatric Endocrinology at Queen Mary University of London and Barts and the Royal London Hospital. Her major clinical and research interests include paediatric Cushing's syndrome, the genetics of growth hormone insensitivity (GHI) and the molecular basis of adrenal disorders. She has published widely on many aspects of the investigation and management of Cushing's disease.

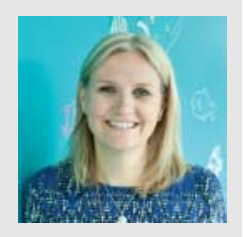

(C) 2015 European Society of Endocrinology Printed in Great Britain
Published by Bioscientifica Ltd. 
secreting corticotroph adenomas in childhood account for $54.8 \%$ of all pituitary adenomas from age 0 to 11 years and $29.4 \%$ from 12 to 17 years (5). Therefore, CD is the commonest cause of CS after the pre-school years, accounting for more than half of pituitary adenomas under the age of 11 years. CD accounts for $\sim 75 \%$ of all cases of CS in children over 5 years. In children under 5 years, primary adrenal causes (adenoma, carcinoma or bilateral adrenal hyperplasia) are the most common causes of CS (6).

In 182 cases of paediatric $C D$ taken from the literature, the median age of presentation was 14.1 years (7). The mean age at presentation in our own series was slightly younger at $12.3 \pm 3.5$ years (range 5.7-17.8) (8). In adults, $\mathrm{CD}$ has a female preponderance, however male predominance is now established in prepubertal subjects $(3,9)$, with an overall prevalence of males (63\%) compared with females $(79 \%)$ in paediatric and adult series respectively (8). The incidence in males and females during puberty was equal, with an increasing predominance of females in post-pubertal patients (9). No clear explanation for this phenomenon exists. In addition, male paediatric patients may have more aggressive disease with elevated BMI, shorter height and higher ACTH levels compared with females (10). The basis for this possible gender-dependent biological difference is currently unclear.

\section{Pathogenesis}

Pituitary microadenomas, frequently with diameter $<5 \mathrm{~mm}(11,12)$, are the commonest cause of $\mathrm{CD}$ in children. At surgery, corticotroph adenomas are frequently observed to have a diameter of $2 \mathrm{~mm}$ or less (5). Pituitary macroadenomas (defined as $>1 \mathrm{~cm}$ in maximal diameter) account for $\sim 10 \%$ of adult-onset CD but are extremely rare in children. Two cases of a corticotroph macroadenomas have been identified in our series of 47 paediatric cases $(4 \%)(8,13)$.

\section{Molecular pathogenesis}

The majority of patients with paediatric $\mathrm{CD}$ do not have causative germline genetic defects (14). However, somatic mutations of the USP8 deubiquitinase gene in corticotroph adenomas have recently been implicated in the molecular pathogenesis of $\mathrm{CD}$ (15). The molecular genetic processes leading to $\mathrm{CD}$ are poorly understood, but an association with several rare hereditary conditions has been noted. Multiple endocrine neoplasia type 1 (MEN1) is an autosomal-dominant disorder characterised by endocrine tumours including anterior pituitary adenomas, and MEN1-associated ACTH-producing adenomas have been reported in several young patients (16). Pituitary macroadenomas have also been reported to be an early manifestation of MEN1 (17).

Mutations in the aryl hydrocarbon receptor-interacting protein $(A I P)$ gene predispose to familial pituitary adenomas (18). However, only one out of $73(1.4 \%)$ paediatric $\mathrm{CD}$ subjects were found to have an AIP mutation (19). Therefore genetic defects are extremely rare in sporadic, isolated paediatric CD. However, careful family history for features of MEN1 and familial pituitary adenomas is warranted in children presenting with CD, and genetic testing should be performed in cases with a positive family history.

\section{Clinical features}

The rarity of paediatric CS in clinical practice underlies the fact that this diagnosis may be overlooked. However, early recognition of the salient features of $\mathrm{CD}$ is crucial to allow prompt diagnosis and effective treatment. The features of paediatric CD are well documented (7) and have shown some interesting differences compared with adult patients (8) (Table 1). Key presenting features in children include weight gain, a change in facial appearance and growth failure. In our series of paediatric CD patients, all but one child had evidence of weight gain (mean BMI SDS at diagnosis $2.7 \pm 1.6$; range $0.0-9.2$ ) and all patients had

Table 1 Clinical features and age at diagnosis in paediatric and adult-onset CD. Data from Storr et al. (8).

\begin{tabular}{|c|c|c|c|c|}
\hline \multirow[b]{2}{*}{ Clinical feature } & \multirow{2}{*}{$\begin{array}{c}\text { Adult CD } \\
\text { subjects } \\
(n=183) \\
\text { No. with } \\
\text { symptom } \\
\text { or sign (\%) }\end{array}$} & \multicolumn{2}{|c|}{$\begin{array}{c}\text { Paediatric } \\
\text { CD subjects } \\
(n=41)\end{array}$} & \multirow[b]{2}{*}{$P$ value } \\
\hline & & $\begin{array}{c}\text { No. with } \\
\text { symptom } \\
\text { or sign (\%) }\end{array}$ & $\begin{array}{c}\text { Mean } \\
\text { age } \pm \text { s.D. } \\
\text { (years) }\end{array}$ & \\
\hline Weight gain & $119(65)$ & $40(98)$ & $12.3 \pm 3.5$ & 0.001 \\
\hline Weight loss & $8(4)$ & $1(2)$ & (age 13.2) & 0.87 \\
\hline Facial changes & $154(81)$ & $41(100)$ & $12.3 \pm 3.5$ & 0.01 \\
\hline Fatigue & $48(26)$ & $25(61)$ & $11.6 \pm 3.6$ & $<0.0001$ \\
\hline Virilisation & $41(22)$ & $16 / 21(76)$ & $10.5 \pm 2.8$ & $<0.0001$ \\
\hline Hirsutism & $125(68)$ & $24(59)$ & $12.6 \pm 3.3$ & 0.37 \\
\hline $\begin{array}{l}\text { Emotional lability/ } \\
\text { depression }\end{array}$ & 75 (41) & 24 (59) & $11.8 \pm 3.1$ & 0.006 \\
\hline Headaches & $57(31)$ & $21(51)$ & $12.7 \pm 3.2$ & 0.02 \\
\hline Striae & $73(40)$ & $20(49)$ & $14.2 \pm 2.6$ & 0.38 \\
\hline Hypertension & 140 (77) & $20(49)$ & $11.8 \pm 3.5$ & 0.0009 \\
\hline Acne & $49(27)$ & $18(44)$ & $13.9 \pm 2.2$ & 0.05 \\
\hline
\end{tabular}


a change in facial appearance (8). Although there is a spectrum of features, most children and adolescents have a typical Cushingoid appearance. Subtle or sub-clinical presentation or even cyclical features appear to be uncommon. The disease onset is often insidious and parents and family doctors may fail to recognise the pathological nature of the change in the child's appearance, significantly delaying diagnosis. The mean length of symptoms before diagnosis in 43 paediatric CD patients was $2.5 \pm 1.7$ years (range $0.3-6.6$ years) (8).

Growth failure, traditionally recognised as a key clinical feature of hypercortisolaemia in children, may be less obvious. In our series, only $37 \%$ of 52 children with CS due to a range of aetiologies, actually had short stature (height $\leq-2$ s.D.) at diagnosis but growth velocity when available was subnormal in all patients (Fig. 1) (H Storr 2014, unpublished observations). However, at presentation, over $95 \%$ of subjects demonstrated a striking contrast between height SDS, which was almost always below 0 , and BMI SDS, which was usually elevated above 1.5 SDS (7). This auxological feature distinguishes CS from subjects with simple obesity, where most children are tall (20).

A further important aspect of the physical assessment in paediatric patients with $\mathrm{CD}$ is examination of secondary sexual development. The majority of children show signs of abnormal virilisation with advanced pubic hair and genital growth in boys in association with pre-pubertal testicular volumes or pubic hair growth in girls with prepubertal breast development. These features indicate abnormal exposure to adrenal androgens combined with gonadotrophin deficiency (21).

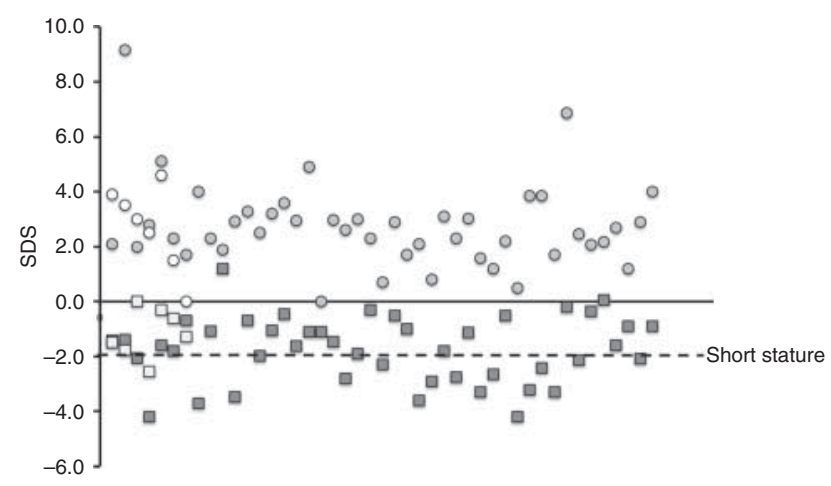

Figure 1

Height and BMI SDS values at diagnosis in paediatric Cushing's syndrome $(n=54)$. Circles and squares represent $\mathrm{BMI}$ and height SDS respectively: light and dark grey, paediatric patients with Cushing's disease (CD); white, CS of other aetiologies.
Striae and acne were present in 49 and $44 \%$ of patients respectively and were commoner in older patients (mean age $14.2 \pm 2.6$ and $13.9 \pm 2.2$ years). The young child with $\mathrm{CD}$ may present with obesity and growth failure alone, without other classical features such as plethora, hirsutism, acne and striae. Additional features commonly reported in our cohort included emotional lability (60\%), fatigue (60\%) and hypertension (49\%). Muscle weakness and easy bruising were rare symptoms (Table 1) (8).

Therefore five key features, namely a change in facial appearance, weight gain, height SDS around or below 0 S.D., elevation of BMI and the presence of genital virilisation should alert the clinician to the possibility of $\mathrm{CD}$ and initiate laboratory evaluation.

\section{Diagnostic guidelines}

\section{Biochemical evaluation}

Before embarking on biochemical evaluation to confirm a diagnosis of $\mathrm{CD}$, it is important to exclude other causes of CS such as excess glucocorticoid use (oral, nasal, inhaled, nasal spray and topical treatments), as exogenous CS is much more common than the endogenous form. The investigation of patients with suspected paediatric and adult $C D$ has been extensively reviewed $(1,22,23)$. A consensus statement advised that only those obese children who demonstrated slowing of their growth velocity should be investigated, as a combined reduction in height velocity and increased weight had a high sensitivity and specificity for CD (24).

The algorithm for investigations in children should be based on that performed in adults (22), and consists initially of confirmation or exclusion of the diagnosis of CS followed by investigations to determine the aetiology. The diagnosis of an ACTH-secreting pituitary adenoma follows from the investigation of suspected CS and the demonstration of ACTH-dependent hypercortisolaemia. Our published protocol for diagnosis of $\mathrm{CD}$, in which the initial screening tests have a high sensitivity, is given in Table $2(7,25)$.

\section{Confirmation or exclusion of hypercortisolaemia}

Key biochemical features of hypercortisolaemia are increased 24-h urinary free cortisol (UFC) excretion, loss of serum cortisol circadian rhythm with detectable cortisol at midnight and failure of suppression of cortisol during the low-dose dexamethasone suppression test (LDDST). UFC measurements in children with hypercortisolaemia 
Table 2 Protocol for diagnosis of paediatric Cushing's disease (ACTH-secreting adenomas). Data from Guaraldi et al. (25).

\begin{tabular}{l} 
Type of test \\
\hline A. Confirmation of Cushing's syndrome \\
1. Urinary free cortisol excretion ( $24-\mathrm{h}$ urine collection) \\
for 3 days \\
2. Serum cortisol circadian rhythm study $(0900 \mathrm{~h}, 1800 \mathrm{~h}$, \\
midnight (sleeping)) \\
3. Low-dose dexamethasone suppression test (LDDST) \\
a. Dose $0.5 \mathrm{mg} 6 \mathrm{~h}(0900,1500,2100,0300 \mathrm{~h})$ for $48 \mathrm{~h}$ \\
b. Dose for patients weighing $<40 \mathrm{~kg} ; 30 \mu \mathrm{g} / \mathrm{kg}$ per day \\
C. Serum cortisol measured at 0,24 and $48 \mathrm{~h}$ \\
B. Confirmation of CD \\
1. Plasma ACTH ( $0900 \mathrm{~h}$ ) \\
2. CRH test ( $1.0 \mu \mathrm{g} / \mathrm{kg}$ i.v.) \\
3. Pituitary MRI scan \\
4. Bilateral inferior petrosal sinus sampling for ACTH \\
(with i.v. CRH)
\end{tabular}

aData from references $(24,26,66)$.

${ }^{b}$ Diagnostic cut-offs refer to midnight serum cortisol values. have a reported sensitivity of $88 \%$ and specificity of $90 \%$ (26), suggesting that UFC alone may not be an ideal screening test. If there is doubt about the interpretation of these values, we recommend hospitalisation for the measurement of serum cortisol at three time points (0900 h, $1800 \mathrm{~h}$, and midnight (sleeping)) to assess circadian rhythm. Assessment of midnight cortisol in the sleeping child gives the highest sensitivity and specificity for the diagnosis of hypercortisolaemia (99 and 100\% respectively using a cut-off of $\geq 121 \mathrm{nmol} / \mathrm{l}, \geq 4.4 \mu \mathrm{g} / \mathrm{dl}$ ) (26). Late night salivary cortisol has also been evaluated in the paediatric obese population and a high sensitivity and specificity for hypercortisolaemia (95.2 and 100\%, respectively) has been reported (27); however, the influence of age has not been characterised. Following the assessment of midnight cortisol, a LDDST is performed, using the adult dose regimen of $0.5 \mathrm{mg}$ every $6 \mathrm{~h}$ (at 0900, 1500, 2100 and $0300 \mathrm{~h}$ ) for $48 \mathrm{~h}$, unless the child weighs $<40 \mathrm{~kg}$ when the NIH-recommended dose is $30 \mu \mathrm{g} / \mathrm{kg}$ per day (3). The LDDST also has a high sensitivity (>90\%) for CS due to multiple causes, and is therefore a useful screening test for paediatric patients in an out-patient setting (22). The $1 \mathrm{mg}$ overnight dexamethasone test has also been used in children, but there are no available data on its interpretation or reliability.

\section{Confirmation of CD}

Following confirmation of hypercortisolism, the priority is to determine its cause. CD is most easily confirmed by determination of basal plasma ACTH. In all patients with

Diagnostic cut-off

$>70 \mu \mathrm{g} / \mathrm{m}^{2}(193 \mathrm{nmol} / 24 \mathrm{~h})$

$\geq 1.8 \mu \mathrm{g} / \mathrm{dl}(50 \mathrm{nmol} / \mathrm{l})^{\mathrm{b}}$

$\geq 1.8 \mu \mathrm{g} / \mathrm{dl}(50 \mathrm{nmol} / \mathrm{l})$

$>5 \mathrm{pg} / \mathrm{ml}(1.1 \mathrm{pmol} / \mathrm{l})$

Cortisol increase $14-22 \%$

Adenoma detection

Central:peripheral ACTH

ratio $\geq 3$ (after i.v. $\mathrm{CRH}$ )
Sensitivity (\%) ${ }^{\text {a }}$

Specificity (\%)

88

90

$100^{b}$

$60^{\mathrm{b}}$

95

80

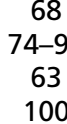

100

$88-100$

92
CD, ACTH is detectable, and using a cut-off value of $29 \mathrm{ng} / \mathrm{l}$, sensitivity and specificity are reported as 70 and $100 \%$ respectively (26). In ACTH-independent CS, ACTH is always low and usually undetectable.

A CRH test using human sequence CRH ( $1 \mu \mathrm{g} / \mathrm{kg}$ i.v. $)$ is also recommended and in 36 of 39 (92\%) CD patients serum cortisol increased by $>20 \%$ (range of cortisol increase from baseline 2-454\%) (8). Ectopic ACTH syndrome is so rare in children that the need for a CRH test is questionable; however, an increased cortisol response contributes to the diagnosis of CD. In addition, a high sensitivity and specificity (97.5 and 100\% respectively) is reported for a cortisol increase of $>20 \%$ following CRH administration (26).

\section{Radiological imaging}

Magnetic resonance imaging (MRI) has superseded previous techniques for pituitary visualisation. MRI scanners currently use 3-T magnetic field strengths to improve signal-to-noise ratios, therefore further improving image quality $(12,28,29,30)$. T2-weighted imaging offers additional identification of cystic components, with post-contrast sequences improving the conspicuity of small lesions, 2-3 $\mathrm{mm}$ thin imaging slices being optimal for their detection. Pituitary adenomas are generally hypointense compared with the adjacent gland and take up contrast less avidly and in a more delayed fashion, and therefore fail to enhance with gadolinium (Fig. 2). On pituitary post-contrast MR scanning, 63 and 55\% of the corticotroph adenomas were identified in two large 

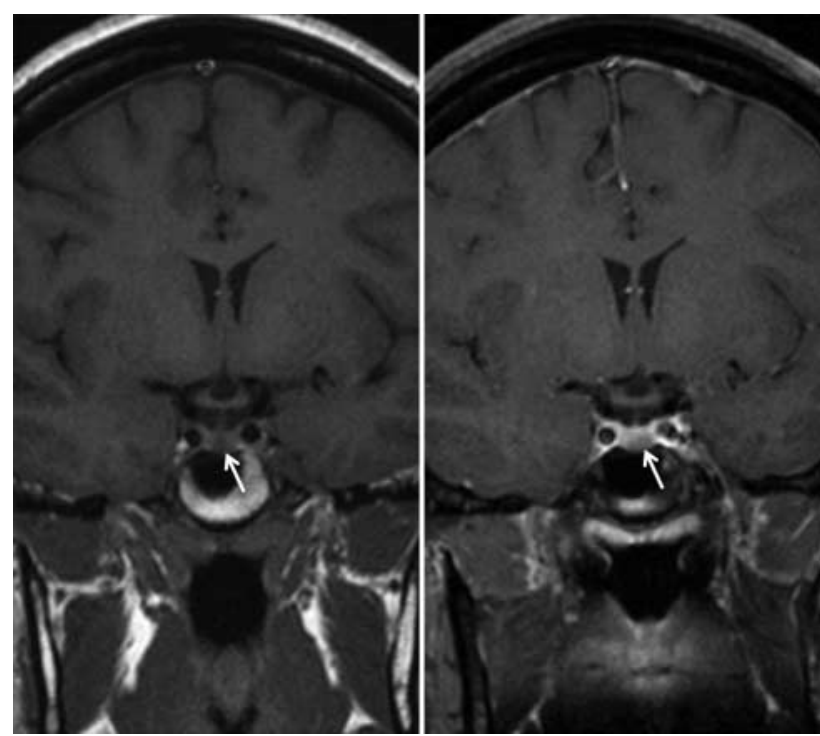

\section{Figure 2}

A left-sided pituitary corticotroph adenoma in an 8.8-year-old boy with Cushing's disease. T1 weighted coronal MRI image before gadolinium (left) and after gadolinium (right). White arrows indicate corticotroph adenoma, which typically enhances less than the background pituitary gland after contrast administration.

paediatric series $(8,31)$. This relatively poor visualisation rate in children could be explained by the limited spatial resolution of MRI, i.e. small lesions within a small pituitary gland are less conspicuous. Therefore, pituitary MRI imaging alone cannot be relied upon to predict the adenoma position or to confirm the diagnosis of paediatric CD.

\section{Bilateral simultaneous inferior petrosal sinus sampling}

Bilateral simultaneous inferior petrosal sinus sampling (BSIPSS) was initially piloted in adults at the NIH (32) to enable distinction between CD and ectopic ACTH syndrome and also to provide a method of identifying a lateral vs central source of ACTH secretion within the pituitary (22). It has now become routine in adult practice unless the MRI unequivocally shows a pituitary adenoma. In children, ectopic ACTH secretion is extremely rare and so the primary aim of BSIPSS is to contribute to the localisation of the microadenoma by demonstrating lateral or midline ACTH secretion. The first paediatric data were reported in the large $\mathrm{NIH}$ series where a predictive value of lateralisation was $75-80 \%(1,3)$.
BSIPSS is a highly specialised technique and should be performed by the same radiologist who regularly studies adult patients. In the majority of cases, general anaesthesia (GA) is not required so that potential alteration of ACTH secretion is avoided. However, in young children GA may be necessary. In our centre, BSIPSS has been performed in 35 paediatric CD patients without complications. The results suggest that ACTH sampling gives a better prediction of the site of the microadenoma than that by pituitary MR imaging $(8,33)$. A more recent study from the NIH described its further experience of BSIPSS in 94 paediatric patients and reported that localisation of ACTH secretion concurred with the site of the adenoma at surgery in $58 \%$ of cases, concluding that the technique was not an essential part of a paediatric investigation protocol (34). The percentage of predictive lateralisation, however, increased to $70 \%(51 / 73)$ after exclusion of 18 centrally located lesions and four bilateral lesions.

\section{Treatment}

\section{Paediatric and adult co-operation}

As mentioned previously, $C D$ is extremely rare in the paediatric age range, and even an experienced paediatric endocrine unit may only see a handful of cases during a 20-year period. Consequently, paediatric endocrinologists may not acquire the experience to manage these patients with expertise. For this reason, collaboration with a specialised adult endocrinology unit with experience of CS is essential. The combined expertise in medical management, pituitary surgery and pituitary radiotherapy (RT) will greatly benefit the patient.

\section{Pituitary surgery: selective microadenomectomy}

Transsphenoidal surgery (TSS) is regarded as a safe and effective procedure in children $(35,36,37,38)$, and is now considered as a first-line therapy as it involves selective removal of the adenoma, maximising the potential for normal pituitary tissue to remain in situ. The small size of ACTH-secreting adenomas and the pituitary fossa in children in association with absent aeration of the sphenoid bone in young patients add to the technical difficulty of TSS. The outcome of TSS depends on the definition of post-operative 'cure' or remission (Table 3). In a recent report of 200 cases of paediatric CD, 98\% were in remission post-surgery (12) and 97\% of the subjects who were in biochemical remission had hypocortisolaemia. In all the published series where 'remission' is described, 
Table 3 Reported cure rates and long-term pituitary function following first-line transsphenoidal surgery (TSS) in childhood CD.

\begin{tabular}{|c|c|c|c|c|c|}
\hline Series & No. CD patients & Age (years) & $\begin{array}{l}\text { No. of } \\
\text { first-line TSS }\end{array}$ & Outcome & $\begin{array}{l}\text { Long-term pituitary } \\
\text { deficiencies }\end{array}$ \\
\hline NIH, Bethesda, USA (12) & 200 & $4.0-19.0$ & $\begin{array}{r}173 / 200 \\
(87 \%)\end{array}$ & $189 / 200(95 \%)$ cured $^{a}$ & $\begin{array}{l}10 / 200(5 \%) \mathrm{DI} \\
\text { Incomplete data }\end{array}$ \\
\hline Barts Health, London (8) & $\begin{array}{l}41 \text { (one } \\
\text { macroadenoma) }\end{array}$ & $5.7-17.8$ & $36 / 41(88 \%)$ & $\begin{array}{l}\text { 24/35 (69\%) } \text { cured }^{a} \\
\text { (macroadenoma } \\
\text { not cured) }\end{array}$ & $\begin{array}{l}11 / 24(46 \%) \mathrm{GH} \\
2 / 24(8 \%) \text { DI } \\
2 / 24(8 \%) \text { Hypopit }\end{array}$ \\
\hline São Paulo, Brazil (67) & 15 & $6.0-18.0$ & 15 & $9 / 15(60 \%)$ cured $^{a}$ & $\begin{array}{l}1 / 9(11 \%) \text { Hypopit } \\
1 / 9(11 \%) \mathrm{GH} \\
1 / 9(11 \%) \mathrm{DI}\end{array}$ \\
\hline Mumbai, India (44) & 48 & $9.0-19.0$ & 48 & $27 / 48(56 \%)$ cured $^{a}$ & Not published \\
\hline Virginia, USA (37) & 33 & $5.0-19.0$ & 33 & $76 \%$ cured $^{a}$ & $\begin{array}{l}1 / 33(3 \%) \text { ACTH } \\
1 / 33(3 \%) \text { DI } \\
\text { Incomplete data }\end{array}$ \\
\hline $\begin{array}{l}\text { Great Ormond Street } \\
\text { Hospital, London (35) }\end{array}$ & 12 & $8.7-16.3$ & 12 & $\begin{array}{l}9 / 12(75 \%) \text { (clinical and } \\
\text { biochemical remission) }\end{array}$ & $\begin{array}{l}7 / 9(78 \%) \mathrm{GH} \\
4 / 9(44 \%) \mathrm{ACTH} \\
4 / 9(44 \%) \mathrm{GT} \\
3 / 9(33 \%) \mathrm{TSH} \\
1 / 9(11 \%) \mathrm{DI}\end{array}$ \\
\hline $\begin{array}{l}\text { Rochester, Minnesota, } \\
\text { USA (68) }\end{array}$ & $\begin{array}{l}22 \text { (one } \\
\text { macroadenoma) }\end{array}$ & $10.1-18.9$ & 22 & $\begin{array}{l}\text { 10/22 (45\%) } \text { cured }^{\text {a }} \\
\text { (macroadenoma } \\
\text { not cured) }\end{array}$ & $\begin{array}{l}1 / 22(5 \%) \mathrm{TSH} \\
\text { Incomplete data }\end{array}$ \\
\hline NIH, Bethesda, USA (3) & 50 & Mean $14.4 \pm 4$ & $37 / 50(74 \%)$ & $35 / 37(95 \%)$ cured $^{a}$ & $\begin{array}{l}6 / 37(16 \%) \mathrm{TSH} \\
3 / 37(8 \%) \mathrm{DI} \\
3 / 37(8 \%) \mathrm{GH} \\
1 / 37(3 \%) \mathrm{GT}\end{array}$ \\
\hline Suresnes, France (69) & 36 & $\leq 16.0$ & $\begin{array}{l}\text { 33/36 }(92 \%) \\
(23 \text { selec- } \\
\text { tive, eight } \\
\text { subtotal) }\end{array}$ & $\begin{array}{l}\text { 23/33 (69\%) } \\
\text { (hypocortisolaemia or } \\
\text { 'physiological' cure) }\end{array}$ & $\begin{array}{l}1 / 33(3 \%) \text { DI } \\
1 / 33(3 \%) \text { Hypopit } \\
\text { Incomplete data }\end{array}$ \\
\hline
\end{tabular}

$\mathrm{CD}$, Cushing's disease; GH, growth hormone; DI, cranial diabetes insipidus; Hypopit, pan-hypopituitarism; ACTH, adrenocorticotrophic hormone; GT, gonadotrophins; TSH, thyroid-stimulating hormone.

${ }^{a}$ 'Cure' defined as undetectable serum cortisol in the immediate post-operative period $(<50 \mathrm{nmol} / \mathrm{l})$.

recurrences of post-TSS hypercortisolaemia have occurred, which were treated either by pituitary re-operation or by pituitary RT. In the two paediatric series, where 'cure' was defined as post-operative serum cortisol levels of $<1 \mu \mathrm{g} / \mathrm{dl}$ $(28 \mathrm{nmol} / \mathrm{l})(3)$ or $<1.8 \mu \mathrm{g} / \mathrm{dl}(50 \mathrm{nmol} / \mathrm{l})(8)$, the reported 'cure' rates were 100 and $69 \%$ respectively. Follow-up data indicate that recurrence rates of $\mathrm{CD}$ in these patients were very low $(8,31)$. Initial post-operative remission in children was associated with identification of the adenoma at surgery and long-term remission correlated with younger age, smaller adenoma and morning serum cortisol level of $<1 \mu \mathrm{g} / \mathrm{dl}(28 \mathrm{nmol} / \mathrm{l})$ after surgery (12). Lasting remission in children is observed in those patients with younger age, smaller tumour size and absence of cavernous sinus or dural invasion (12). However, recurrence of $\mathrm{CD}$ in adults has been reported up to 15 years after apparent surgical cure, even in individuals who had very low or undetectable post-operative cortisol levels (39). Therefore lifelong follow-up for children treated for CD is essential.

\section{Endoscopic pituitary surgery}

More recently the less invasive technique of endonasal endoscopic transsphenoidal pituitary surgery (ETES) has been used in some centres, and in adult patients has shown equivalent rates of complete tumour resection, shorter hospital stays, decreased patient discomfort and reduced or equivalent surgical complications $(40,41)$. In children, ETES may be preferable as the first-line treatment and for recurrent lesions, being potentially advantageous in terms of efficacy and safety with reduction of surgical trauma, pain perception, paediatric intensive care unit admissions, need for blood transfusions, anterior pituitary deficiencies and incidence of diabetes insipidus $(13,42,43)$. Although paediatric experience with endonasal ETES is limited, preliminary results in children with $\mathrm{CD}$ have recently been reported and shown an excellent outcome (13). With more experience, ETES could become the standard surgical approach in children, as has been now practised in adults. 


\section{Pituitary RT}

A proportion of paediatric patients who undergo TSS for $\mathrm{CD}$ do not achieve post-operative cure or remission $(44,45,46)$. The options for second-line therapy are repeat TSS, pituitary RT, long-term medical therapy to control hypercortisolaemia and bilateral adrenalectomy. External pituitary RT is known to be effective in children with CD with a more rapid mode of action than in adult patients. Stereotactic RT and gamma knife approaches are now available and utilised in adult $\mathrm{CD}$; however, experience is limited, particularly in children. Centres using RT have administered irradiation from a 4 - to $15-\mathrm{MeV}$ linear accelerator, via a three-field technique (two lateral, one frontal) to deliver a total dose of $45 \mathrm{~Gy}$ in 25 fractions over 35 days (45). The effectiveness and rapid onset of this therapy were confirmed in three small series. In the first, seven children were treated by RT and all were cured with a mean interval of 0.94 years (range 0.25-2.86) (45). In the second series, eight subjects were treated and four were cured in 9-18 months after RT (44). In the third series, a total of 12 out of 15 patients were cured within 18 months of RT and ten of these were cured within 9 months of treatment (47). In a further series, eight children were treated with stereotactic external RT using 60 Co gamma radiation. Seven of the eight subjects were cured during the first year after completion of therapy (48).

Anterior pituitary function after RT was studied and growth hormone $(\mathrm{GH})$ deficiency was present in five out of six subjects tested with peak $\mathrm{GH}<6 \mathrm{ng} / \mathrm{ml}$ at a mean interval after RT of 1.0 years (range 0.11-2.54) (49). On retesting at an interval of 9.3 years (range 7.6-11.3) in three out of four subjects, GH secretion had recovered (peak GH 6.4-16.5 ng/ml). Thyroid function, PRL and testicular volume were normal. GH deficiency and hypogonadism were also documented in seven children successfully treated with higher doses of 50-70 Gy $(44,48)$. Children receiving pituitary RT for $\mathrm{CD}$ require regular assessment of anterior pituitary function post-therapy.

\section{Medical therapy and bilateral adrenalectomy}

Definitive treatments such as surgery and/or RT, rather than long-term medical therapies, are currently recommended for the management of paediatric CD. Medical therapies for paediatric CD are currently limited (46) and not well studied, but they can be used to urgently lower cortisol levels in very sick patients, to normalise the hypercortisolaemia in preparation for surgery or whilst awaiting the effects of RT. Adrenal steroidogenesis inhibitors such as metyrapone and ketoconazole are well tolerated and can be highly effective at reducing cortisol levels either alone or in combination (6). However, control may be lost due to the oversecretion of corticotrophin and may not be effective for long-term treatment. Intravenous administration of etomidate has successfully controlled hypercortisolaemia in children with $\mathrm{CD}$, who were either too unwell for TSS or presented with acute unmanageable symptoms such as respiratory failure or severe psychosis $(50,51)$. Bilateral adrenalectomy remains a therapeutic option for CD in life-threatening situations or where TSS is not possible or available. Although Nelson's syndrome, a potentially life-threatening complication, appears to be more frequent in children than in adults and often requires pituitary surgery or RT (52).

\section{Post-cure growth and development and pituitary function}

Growth failure is almost always seen at diagnosis in paediatric patients with $C D(1,53)$. Virilisation may lead to acceleration of bone age and may further compromise growth potential (54). A key article from the NIH described the abnormalities of height and GH secretion (55) together with a poor outcome for post-treatment catchup growth and adult height (56). Disappointing post-cure catchup was also reported, attributed to continuing GH deficiency, occurring either from TSS, pituitary RT or the long-standing effects of chronic hypercortisolaemia on pituitary and growth plate physiology (53). The challenge is to reverse these problems and maximise growth potential so as to achieve acceptable adult height and body composition.

In the absence of catchup growth, we recommend that GH deficiency is investigated at 3-6 months after TSS or completion of RT. If required, GH therapy should be initiated without delay and GNRH analogue therapy may be added to delay puberty and epiphyseal closure. Results demonstrate that this regime usually enables adequate catchup growth and adult height within range of target height for the majority of patients (57). Combined treatment with GH and aromatase inhibitors may also be a therapeutic alternative in pubertal patients (58).

Normal body composition is more difficult to achieve. Many patients remain obese and BMI SDS was elevated $(P<0.01)$ at a mean interval of 3.9 years after cure in 14 patients (57). A long-term follow-up study of childhood and adolescent $\mathrm{CD}$ showed that total body fat and the ratio of visceral-to-subcutaneous fat remained abnormally high in the majority of patients studied 7 years after cure (59). 
The implications of chronic excess visceral fat in terms of risk for adult metabolic syndrome deserve future study. Bone mineral density (BMD) was closer to normal together with some patients having normal BMD at diagnosis (60).

A summary of reported long-term pituitary deficiencies following first-line TSS in children with CD is given in Table 3. Pituitary function was analysed in six patients at intervals of 6.6-16.5 years after receiving RT and have shown that although GH deficiency was frequent initially, some recovery occurred in adult life (49). Gonadotrophin secretion was generally preserved with normal or early puberty; the latter being a well-recognised complication of cranial RT (61). Thyroid-stimulating hormone and ACTH deficiencies were minimal (49). It is important to note that the risk of hypopituitarism may continue to increase in the years after radiation.

Studies of adult CS patients have reported brain atrophy, cognitive impairment and psychopathology, most commonly depression, associated with excess endogenous circulating glucocorticoids (62). A study from the NIH (63) also found significant cerebral atrophy in children with $\mathrm{CD}$ at diagnosis; however, there was no difference in IQ scores between patients and controls. Interestingly, this study also reported an almost complete reversal of the cerebral atrophy as has been observed in association with hypercortisolaemia-induced severe psychosis (50). However in the former study, a significant decline in cognitive function 1 year after cure by TSS was noted despite reversal of the radiological abnormalities. This is in contrast to adult studies, which report reversible cognitive impairment and reversible loss of brain volume associated with eucortisolaemia $(63,64)$. More recently, the NIH group reported that children with $\mathrm{CD}$ have impaired health-related quality of life which does not fully resolve 1 year post treatment (65).

\section{Conclusions and future perspectives}

CS rarely occurs in children and thus the paediatrician may be relatively unprepared in terms of diagnosis and management. A close liaison with adult endocrinology colleagues with more experience is strongly advised and will directly enhance the clinical care of these challenging patients. Paediatric CD manifests a number of characteristic features distinct from adult $\mathrm{CD}$, most notably the significant impact on linear growth and pubertal development. Early diagnosis remains a major challenge because of the frequent lack of appreciation of the nature of the pathology by parents and family doctors.
Once suspected, the patient requires investigation using a formal protocol and the choice and interpretation of tests should be discussed with an adult specialist with experience of $\mathrm{CD}$. Referral should be considered to a centre combining paediatric and adult endocrinology, BSIPSS, TSS and pituitary RT. A specialised multidisciplinary approach to define the optimal therapeutic strategy is essential. In addition, choosing a neurosurgeon experienced in TSS in children is likely to significantly improve the chance of effective and curative therapy. The less invasive technique of ETES provides an alternative to conventional transsphenoidal microscopic surgery in managing paediatric $\mathrm{CD}$.

In experienced hands, the prognosis for cure is good in the majority of children and adolescents with $\mathrm{CD}$, and full recovery of the hypothalamic-pituitary-adrenal axis is possible. However, post-treatment management frequently presents challenges for optimisation of growth, puberty and body composition and deserves further investigation. Longitudinal studies are also needed to formally assess potential long-term cognitive impairment and psychopathology after cure of childhood CD. In addition, further studies are warranted to identify novel genetic defects associated with pituitary corticotroph cell tumourigenesis and to assess the efficacy of new medical therapies and surgical approaches.

Declaration of interest

The authors declare that there is no conflict of interest that could be perceived as prejudicing the impartiality of the review.

\section{Funding}

This review did not receive any specific grant from any funding agency in the public, commercial or not-for-profit sector.

\section{References}

1 Magiakou MA \& Chrousos GP. Cushing's syndrome in children and adolescents: current diagnostic and therapeutic strategies. Journal of Endocrinological Investigation 200225 181-194. (doi:10.1007/ BF03343985)

2 Savage MO \& Besser GM. Cushing's disease in childhood. Trends in Endocrinology and Metabolism 19967 213-216. (doi:10.1016/ 1043-2760(96)00089-6)

3 Magiakou MA, Mastorakos G, Oldfield EH, Gomez MT, Doppman JL, Cutler GB, Nieman LK \& Chrousos GP. Cushing's syndrome in children and adolescents, presentation, diagnosis and therapy. New England Journal of Medicine 1994331 629-636. (doi:10.1056/ NEJM199409083311002)

4 Weber A, Trainer PJ, Grossman AB, Afshar F, Medbak S, Perry LA Plowman PN, Rees LH, Besser GM \& Savage MO. Investigation, 
management and therapeutic outcome in 12 cases of childhood and adolescent Cushing's syndrome. Clinical Endocrinology 199543 19-28. (doi:10.1111/j.1365-2265.1995.tb01888.x)

5 Kunwar S \& Wilson CB. Pediatric pituitary adenomas. Journal of Clinical Endocrinology and Metabolism 199984 4385-4389. (doi:10.1210/jcem. 84.12.6240)

6 Biller BM, Grossman AB, Stewart PM, Melmed S, Bertagna X, Bertherat J, Buchfelder M, Colao A, Hermus AR, Hofland LJ et al. Treatment of adrenocorticotropin-dependent Cushing's syndrome: a consensus statement. Journal of Clinical Endocrinology and Metabolism 200893 2454-2462. (doi:10.1210/jc.2007-2734)

7 Storr HL, Chan LF, Grossman AB \& Savage MO. Paediatric Cushing's syndrome: epidemiology, investigation and therapeutic advances. Trends in Endocrinology and Metabolism 200718 167-174. (doi:10.1016/ j.tem.2007.03.005)

8 Storr HL, Alexandraki KI, Martin L, Isidori AM, Kaltsas GA, Monson JP, Besser GM, Matson M, Evanson J, Afshar F et al. Comparisons in the epidemiology, diagnostic features and cure rate by transsphenoidal surgery between paediatric and adult-onset Cushing's disease. European Journal of Endocrinology 2011164 667-674. (doi:10.1530/EJE-10-1120)

9 Storr HL, Isidori AM, Monson JP, Besser GM, Grossman AB \& Savage MO. Pre-pubertal Cushing's disease is more common in males, but there is no increase in severity at diagnosis. Journal of Clinical Endocrinology and Metabolism 200489 3818-3820. (doi:10.1210/jc. 2003-031531)

10 Libuit LG, Karageorgiadis AS, Sina N II, Nguyen May NM, Keil MF, Lodish MB \& Stratakis CA. A gender-dependent analysis of Cushing's disease in childhood: pre- and post-operative follow-up. Clinical Endocrinology 2015. In press. (doi: 10.1111/cen.12644)

11 Fahlbusch R, Honegger J \& Buchfelder M 1994 Neurosurgical management of Cushing's disease in children. In: Savage MO, Bourguignon J-P, Grossman $\mathrm{AB}$, eds. Frontiers in paediatric neuroendocrinology. Oxford: Blackwell; 68-72.

12 Lonser RR, Wind JJ, Nieman LK, Weil RJ, DeVroom HL \& Oldfield EH. Outcome of surgical treatment of 200 children with Cushing's disease. Journal of Clinical Endocrinology and Metabolism 201398 892-901. (doi:10.1210/jc.2012-3604)

13 Storr HL, Drake WM, Evanson J, Matson M, Berney DM, Grossman AB, Akker SA, Monson JP, Alusi G, Savage MO et al. Endonasal endoscopic transsphenoidal pituitary surgery: early experience and outcome in paediatric Cushing's disease. Clinical Endocrinology 201380 270-276. (doi:10.1111/cen.12275)

14 Cuny T, Pertuit M, Sahnoun-Fathallah M, Daly A, Occhi G, Odou MF, Tabarin A, Nunes ML, Delemer B, Rohmer V et al. Genetic analysis in young patients with sporadic pituitary macroadenomas: besides AIP don't forget MEN1 genetic analysis. European Journal of Endocrinology 2013168 533-541. (doi:10.1530/EJE-12-0763)

15 Reincke M, Sbiera S, Hayakawa A, Theodoropoulou M, Osswald A, Beuschlein F, Meitinger T, Mizuno-Yamasaki E, Kawaguchi K, Saeki Y et al. Mutations in the deubiquitinase gene USP8 cause Cushing's disease. Nature Genetics 201547 31-38. (doi:10.1038/ng.3166)

16 Rix M, Hertel NT, Nielsen FC, Jacobsen BB, Hoejberg AS, Brixen K, Hangaard J \& Kroustrup JP. Cushing's disease in childhood as the first manifestation of multiple endocrine neoplasia syndrome type 1. European Journal of Endocrinology 2004151 709-715. (doi:10.1530/eje.0. 1510709)

17 Stratakis CA, Schussheim DH, Freedman SM, Keil MF, Pack SD, Agarwal SK, Skarulis MC, Weil RJ, Lubensky IA, Zhuang Z et al. Pituitary macroadenoma in a 5-year-old: an early expression of multiple endocrine neoplasia type 1. Journal of Clinical Endocrinology and Metabolism 200085 4776-4780. (doi:10.1210/jcem.85.12.7064)

18 Vierimaa O, Georgitsi M, Lehtonen R, Vahteristo P, Kokko A, Raitila A, Tuppurainen K, Ebeling TM, Salmela PI, Paschke R et al. Pituitary adenoma predisposition caused by germline mutations in the AIP gene. Science 2006312 1228-1230. (doi:10.1126/science.1126100)
19 Stratakis CA, Tichomirowa MA, Boikos S, Azevedo MF, Lodish M, Martari M, Verma S, Daly AF, Raygada M, Keil MF et al. The role of germline AIP, MEN1, PRKAR1A, CDKN1B and CDKN2C mutations in causing pituitary adenomas in a large cohort of children, adolescents, and patients with genetic syndromes. Clinical Genetics $2010 \mathbf{7 8}$ 457-463. (doi:10.1111/j.1399-0004.2010.01406.x)

20 Greening JE, Storr HL, McKenzie SA, Davies KM, Martin L, Grossman AB \& Savage MO. Linear growth and body mass index in pediatric patients with Cushing's disease or simple obesity. Journal of Endocrinological Investigation 200629 885-887. (doi:10.1007/BF03349191)

21 Dupuis CC, Storr HL, Perry LA, Ho JTF, Ahmed L, Ong KK, Dunger DB, Monson JP, Grossman AB, Besser GM et al. Abnormal puberty in paediatric Cushing's disease: relationship with adrenal androgen, sex hormone binding globulin and gonadotrophin concentrations. Clinical Endocrinology 200766 838-843. (doi:10.1111/j.1365-2265. 2007.02822.x)

22 Newell-Price J, Trainer P, Besser M \& Grossman A. The diagnosis and differential diagnosis of Cushing's syndrome and pseudo-Cushing's states. Endocrine Reviews 199819 647-672. (doi:10.1210/edrv.19.5. 0346)

23 Arnaldi G, Angeli A, Atkinson AB, Bertagna X, Cavagnini F, Chrousos GP, Fava GA, Findling JW, Gaillard RC, Grossman AB et al. Diagnosis and complications of Cushing's syndrome: a consensus statement. Journal of Clinical Endocrinology and Metabolism $2003 \mathbf{8 8}$ 5593-5602. (doi:10.1210/jc.2003-030871)

24 Nieman LK, Biller BM, Findling JW, Newell-Price J, Savage MO, Stewart PM \& Montori V. The diagnosis of Cushing's syndrome: an endocrine society clinical practice guideline. Journal of Clinical Endocrinology and Metabolism 200893 1526-1540. (doi:10.1210/ jc.2008-0125)

25 Guaraldi F, Storr HL, Ghizzoni L, Ghigo E \& Savage MO. Paediatric pituitary adenomas: a decade of change. Hormone Research in Paediatrics 201481 145-155. (doi:10.1159/000357673)

26 Batista DL, Riar J, Keil M \& Stratakis CA. Diagnostic tests for children who are referred for the investigation of Cushing syndrome. Pediatrics 2007120 e575-e586. (doi:10.1542/peds.2006-2402)

27 Martinelli CE Jr, Sader SL, Oliveira EB, Daneluzzi JC \& Moreira AC. Salivary cortisol for screening of Cushing's syndrome in children. Clinical Endocrinology 199951 67-71. (doi:10.1046/j.1365-2265.1999. 00749.x)

28 Keil MF \& Stratakis CA. Pituitary tumors in childhood: update of diagnosis, treatment and molecular genetics. Expert Review of Neurotherapeutics 20088 563-574. (doi:10.1586/14737175.8.4.563)

29 Ezzat S, Asa SL, Couldwell WT, Barr CE, Dodge WE, Vance ML \& McCutcheon IE. The prevalence of pituitary adenomas: a systematic review. Cancer 2004101 613-619. (doi:10.1002/cncr.20412)

30 Lucas JW \& Zada G. Imaging of the pituitary and parasellar region. Seminars in Neurology 201232 320-331.

31 Batista DL, Oldfield EH, Keil MF \& Stratakis CA. Postoperative testing to predict recurrent Cushing disease in children. Journal of Clinical Endocrinology and Metabolism 200994 2757-2765. (doi:10.1210/jc. 2009-0302)

32 Oldfield EH, Doppman JL, Nieman LK, Chrousos GP, Miller DL, Katz DA, Cutler GB Jr \& Loriaux DL. Petrosal sinus sampling with and without corticotropin-releasing hormone for the differential diagnosis of Cushing's syndrome. New England Journal of Medicine 1991 325 897-905. (doi:10.1056/NEJM199109263251301)

33 Storr HL, Afshar F, Matson M, Sabin I, Davies KM, Evanson J, Plowman PN, Besser GM, Monson JP, Grossman AB et al. Factors influencing cure by transsphenoidal selective adenomectomy in paediatric Cushing's disease. European Journal of Endocrinology 2005152 825-833. (doi:10.1530/eje.1.01921)

34 Batista D, Gennari M, Riar J, Chang R, Keil MF, Oldfield EH \& Stratakis CA. An assessment of petrosal sinus sampling for localization of pituitary microadenomas in children with Cushing disease. Journal of 
Clinical Endocrinology and Metabolism 200691 221-224. (doi:10.1210/jc. 2005-1096)

35 Massoud AF, Powell M, Williams RA, Hindmarsh PC \& Brook CG. Transsphenoidal surgery for pituitary tumours. Archives of Disease in Childhood 199776 398-404. (doi:10.1136/adc.76.5.398)

36 Knappe UJ \& Ludecke DK. Transnasal microsurgery in children and adolescents with Cushing's disease. Neurosurgery 199639 484-493.

37 Kanter AS, Diallo AO, Jane JA Jr, Sheehan JP, Asthagiri AR, Oskouian RJ, Okonkwo DO, Sansur CA, Vance ML, Rogol AD et al. Single-center experience with pediatric Cushing's disease. Journal of Neurosurgery 2005103 413-420.

38 Joshi SM, Hewitt RJ, Storr HL, Rezajooi K, Ellamushi H, Grossman AB, Savage MO \& Afshar F. Cushing's disease in children and adolescents: 20 years of experience in a single neurosurgical center. Neurosurgery 200557 281-285 discussion 281-285. (doi:10.1227/01.NEU. $0000166580.94215 .53)$

39 Alexandraki KI, Kaltsas GA, Isidori AM, Storr HL, Afshar F, Sabin I, Akker SA, Chew SL, Drake WM, Monson JP et al. Long-term remission and recurrence rates in Cushing's disease: predictive factors in a singlecentre study. European Journal of Endocrinology 2013168 639-648. (doi:10.1530/EJE-12-0921)

40 Goudakos JK, Markou KD \& Georgalas C. Endoscopic versus microscopic trans-sphenoidal pituitary surgery: a systematic review and meta-analysis. Clinical Otolaryngology 201136 212-220. (doi:10.1111/j. 1749-4486.2011.02331.x)

41 DeKlotz TR, Chia SH, Lu W, Makambi KH, Aulisi E \& Deeb Z. Metaanalysis of endoscopic versus sublabial pituitary surgery. Laryngoscope 2012122 511-518. (doi:10.1002/lary.22479)

42 Massimi L, Rigante M, D'Angelo L, Paternoster G, Leonardi P, Paludetti G \& Di Rocco C. Quality of postoperative course in children: endoscopic endonasal surgery versus sublabial microsurgery. Acta Neurochirurgica 2011153 843-849. (doi:10.1007/s00701-010-0929-6)

43 Chivukula S, Koutourousiou M, Snyderman CH, FernandezMiranda JC, Gardner PA \& Tyler-Kabara EC. Endoscopic endonasal skull base surgery in the pediatric population. Journal of Neurosurgery. Pediatrics 201311 227-241. (doi:10.3171/2012.10.PEDS12160)

44 Acharya SV, Gopal RA, Goerge J, Menon PS, Bandgar TR \& Shah NS. Radiotherapy in paediatric Cushing's disease: efficacy and long term follow up of pituitary function. Pituitary 201013 293-297. (doi:10.1007/s11102-010-0231-x)

45 Storr HL, Plowman PN, Carroll PV, Francois I, Krassas GE, Afshar F, Besser GM \& Grossman AB. Clinical and endocrine responses to pituitary radiotherapy in pediatric Cushing's disase: an effective second line treatment. Journal of Clinical Endocrinology and Metabolism 200388 34-37. (doi:10.1210/jc.2002-021032)

46 Stratakis CA. Cushing syndrome in pediatrics. Endocrinology and Metabolism Clinics of North America 201241 793-803. (doi:10.1016/j. ecl.2012.08.002)

47 Jennings AS, Liddle GW \& Orth DN. Results of treating childhood Cushing's disease with pituitary irradiation. New England Journal of Medicine 1977297 957-962. (doi:10.1056/NEJM197711032971801)

48 Thoren M, Rahn T, Hallengren B, Kaad PH, Nilsson KO, Ravn H, Ritzen M, Petersen KE \& Aarskog D. Treatment of Cushing's disease in childhood and adolescence by stereotactic pituitary irradiation. Acta Paediatrica Scandinavica 198675 388-395. (doi:10.1111/j.1651-2227. 1986.tb10219.x)

49 Chan LF, Storr HL, Plowman PN, Perry LA, Besser GM, Grossman AB \& Savage MO. Long-term anterior pituitary function in patients with paediatric Cushing's disease treated with pituitary radiotherapy. European Journal of Endocrinology 2007156 477-482. (doi:10.1530/EJE-06-0588)

50 Chan LF, Vaidya M, Westphal B, Allgrove J, Martin L, Afshar F, Hindmarsh PC, Savage MO, Grossman AB \& Storr HL. Use of intravenous etomidate to control acute psychosis induced by the hypercortisolaemia in severe paediatric Cushing's disease. Hormone Research in Paediatrics 201175 441-446. (doi:10.1159/000324419)
51 Greening JE, Brain CE, Perry LA, Mushtaq I, Sales Marques J, Grossman AB \& Savage MO. Efficient short-term control of hypercortisolaemia by low-dose etomidate in severe paediatric Cushing's disease. Hormone Research 200564 140-143. (doi:10.1159/000088587)

52 Barber TM, Adams E, Ansorge O, Byrne JV, Karavitaki N \& Wass JA. Nelson's syndrome. European Journal of Endocrinology 2010163 495-507. (doi:10.1530/EJE-10-0466)

53 Lebrethon MC, Grossman AB, Afshar F, Plowman PN, Besser GM \& Savage MO. Linear growth and final height after treatment for Cushing's disease in childhood. Journal of Clinical Endocrinology and Metabolism 200085 3262-3265. (doi:10.1210/jcem.85.9.6817)

54 Hayles AB, Hahn HB Jr, Sprague RG, Bahn RC \& Priestley JT. Hormonesecreting tumors of the adrenal cortex in children. Pediatrics 196637 $19-25$.

55 Magiakou MA, Mastorakos G, Gomez MT, Rose SR \& Chrousos GP. Suppressed spontaneous and stimulated growth hormone secretion in patients with Cushing's disease before and after surgical cure. Journal of Clinical Endocrinology and Metabolism 199478 131-137. (doi:10.1210/ jcem.78.1.7507118)

56 Magiakou MA, Mastorakos G \& Chrousos GP. Final stature in patients with endogenous Cushing's syndrome. Journal of Clinical Endocrinology and Metabolism 199479 1082-1085. (doi:10.1210/jcem.79.4.7962277)

57 Davies JH, Storr HL, Davies K, Monson JP, Besser GM, Afshar F, Plowman PN, Grossman AB \& Savage MO. Final adult height and body mass index after cure of paediatric Cushing's disease. Clinical Endocrinology 200562 466-472. (doi:10.1111/j.1365-2265.2005. 02244.x)

58 Boronat M, Marrero D, Lopez-Plasencia Y, Novoa Y, Garcia-Delgado Y \& Novoa FJ. Combined treatment with GH and anastrozole in a pubertal boy with Cushing's disease and postsurgical GH deficiency. European Journal of Endocrinology 2012166 1101-1105. (doi:10.1530/EJE-120036)

59 Leong GM, Abad V, Charmandari E, Reynolds JC, Hill S, Chrousos GP \& Nieman LK. Effects of child- and adolescent-onset endogenous Cushing syndrome on bone mass, body composition, and growth: a 7-year prospective study into young adulthood. Journal of Bone and Mineral Research 200722 110-118. (doi:10.1359/jbmr.061010)

60 Scommegna S, Greening JP, Storr HL, Davies KM, Shaw NJ, Monson JP, Grossman AB \& Savage MO. Bone mineral density at diagnosis and following successful treatment of pediatric Cushing's disease. Journal of Endocrinological Investigation 200528 231-235. (doi:10.1007/ BF03345378)

61 Nicholl RM, Kirk JM, Grossman AB, Plowman PN, Besser GM \& Savage MO. Acceleration of pubertal development following pituitary radiotherapy for Cushing's disease. Journal of Clinical Oncology 19935 393-394. (doi:10.1016/S0936-6555(05)80095-0)

62 Dorn LD, Burgess ES, Friedman TC, Dubbert B, Gold PW \& Chrousos GP. The longitudinal course of psychopathology in Cushing's syndrome after correction of hypercortisolism. Journal of Clinical Endocrinology and Metabolism 199782 912-919. (doi:10.1210/jcem.82. 3.3834)

63 Merke DP, Giedd JN, Keil MF, Mehlinger SL, Wiggs EA, Holzer S, Rawson E, Vaituzis AC, Stratakis CA \& Chrousos GP. Children experience cognitive decline despite reversal of brain atrophy one year after resolution of Cushing syndrome. Journal of Clinical Endocrinology and Metabolism 200590 2531-2536. (doi:10.1210/jc.2004-2488)

64 McEwen BS. Cortisol, Cushing's syndrome, and a shrinking brain-new evidence for reversibility. Journal of Clinical Endocrinology and Metabolism 200287 1947-1948. (doi:10.1210/jcem.87.5.9999)

65 Keil MF, Merke DP, Gandhi R, Wiggs EA, Obunse K \& Stratakis CA. Quality of life in children and adolescents 1-year after cure of Cushing syndrome: a prospective study. Clinical Endocrinology 200971 326-333. (doi:10.1111/j.1365-2265.2008.03515.x)

66 Shah NS \& Lila A. Childhood Cushing disease: a challenge in diagnosis and management. Hormone Research in Paediatrics 201176 (Suppl 1) 65-70. (doi:10.1159/000329173) 
67 de Oliveira RS, de Castro M, Antonini SR, Martinelli CE Jr, Moreira AC \& Machado HR. Surgical management of pediatric Cushing's disease: an analysis of 15 consecutive cases at a specialized neurosurgical center. Arquivos Brasileiros de Endocrinologia e Metabologia 201054 17-23. (doi:10.1590/S0004-27302010000100004)

68 Leinung MC, Kane LA, Scheithhauer BW, Carpenter PC \& Zimmerman D. Long term follow-up of transsphenoidal surgery for the treatment of Cushing's disease in childhood. Journal of Clinical Endocrinology and Metabolism 199580 2475-2479. (doi:10.1210/ jcem.80.8.7629245)

69 Dyer EH, Civit T, Visot A, Delalande O \& Derome P. Transsphenoidal surgery for pituitary adenomas in children. Neurosurgery 199434 207-212 discussion 212. (doi:10.1227/00006123199402000-00001)

Received 5 January 2015

Revised version received 9 March 2015

Accepted 12 March 2015 